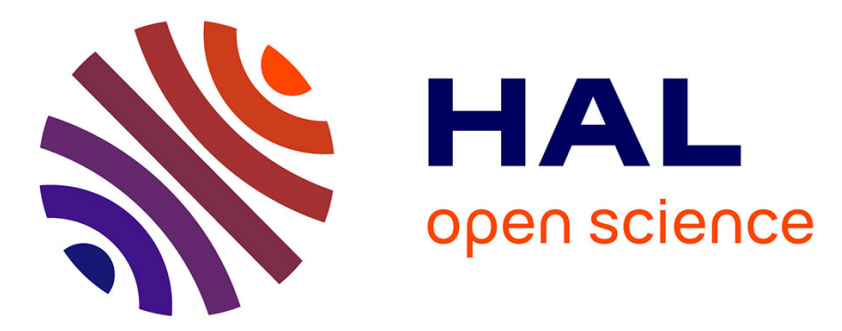

\title{
Ecofriendly Fast Synthesis of Hydrophilic Poly(ethyleneglycol)-Ionic Liquid Matrices for Liquid-Phase Organic Synthesis
}

Joan Fraga-Dubreuil, Marie-Hélène Famelart, Jean-Pierre Bazureau

\section{To cite this version:}

Joan Fraga-Dubreuil, Marie-Hélène Famelart, Jean-Pierre Bazureau. Ecofriendly Fast Synthesis of Hydrophilic Poly(ethyleneglycol)-Ionic Liquid Matrices for Liquid-Phase Organic Synthesis. Organic Process Research and Development, 2002, 6, pp.374-378. 10.1021/op020027y . hal-02244983

\section{HAL Id: hal-02244983 \\ https://hal.science/hal-02244983}

Submitted on 1 Aug 2019

HAL is a multi-disciplinary open access archive for the deposit and dissemination of scientific research documents, whether they are published or not. The documents may come from teaching and research institutions in France or abroad, or from public or private research centers.
L'archive ouverte pluridisciplinaire HAL, est destinée au dépôt et à la diffusion de documents scientifiques de niveau recherche, publiés ou non, émanant des établissements d'enseignement et de recherche français ou étrangers, des laboratoires publics ou privés. 


\title{
Ecofriendly Fast Synthesis of Hydrophilic Poly(ethyleneglycol)-Ionic Liquid Matrices for Liquid-Phase Organic Synthesis.
}

\author{
Joan Fraga-Dubreuil, ${ }^{\dagger}$ Marie-Hélène Famelart, $₫$ and Jean Pierre Bazureau*,$\dagger$ \\ Université de Rennes 1, Institut de Chimie, Synthèse et Electrosynthèse Organiques 3, UMR 6510, Bât. 10A, Campus de \\ Beaulieu, Avenue du Général Leclerc, CS 74205, 35042 Rennes Cedex, France, and INRA, Laboratoire de Recherches de \\ Technologie Laitière, 65 Route de Saint Brieuc, 35042 Rennes Cedex, France
}

\begin{abstract}
:
New, hydrophilic poly(ethyleneglycol)-ionic liquids have been synthesized and investigated, based on 1,3-disubstituted imidazolium cations and fluorinated anions $\left(\mathrm{BF}_{4}^{-}, \mathrm{PF}_{6}^{-}\right.$, $\left(\mathrm{CF}_{3} \mathrm{SO}_{2}\right)_{2} \mathrm{~N}^{-}$, or $\left.\mathrm{NTf}_{2}^{-}\right)$. A series of typical solvent-free reactions have been safely realized using a focused microwave reactor for the preparation of imidazolium chloride precursors in yields ranging from 73 to $94 \%$ followed by quantitative anion metathesis exchanges. The poly(ethyleneglycol)-ionic liquid matrices were also characterized by $\operatorname{NMR}\left({ }^{1} \mathrm{H},{ }^{13} \mathrm{C}\right)$, mass spectrometry (MS), and their dynamic viscosity was determined at $25{ }^{\circ} \mathrm{C}$. These poly(ethyleneglycol)-ionic liquid phases (PEGILPs) as task-specific ionic liquids are promising tools for synthetic applications in liquid-phase combinatorial chemistry.
\end{abstract}

\section{Introduction}

Owing to their interesting chemical and physical properties, room-temperature ionic liquids ${ }^{1}$ (RTILs) are attracting increasing interest as solvent alternatives, mainly as a substitute for conventional volatile organic compounds (VOCs). They have been also referred as "designer solvents"; 2 by a judicious combination of cation and anion and changes in IL, physical properties ${ }^{3}$ have been accomplished by altering the length of alkyl chain attached to the organic cation, ${ }^{4}$ allowing for fine-tuning hydrophobicity, viscosity, and melting points. Because of their lack of vapor pressure and ease of reuse, ILs have been more and more applied in noncatalytic reactions ${ }^{5}$ (in this case the IL is used as a green solvent) and catalytic reactions. ${ }^{6}$

Recent work from our laboratory has shown that benzaldehyde bound to ILs (Figure 1) can be used as a novel matrix in liquid-phase organic synthesis ${ }^{7}$ potentially compatible with

\footnotetext{
* To whom correspondence should be addressed. Fax: + (33) 02232363

74. E-mail: jean-pierre.bazureau@univ-rennes1.fr.

$\dagger$ Université de Rennes.

¥INRA.

(1) (a) Welton, T. Chem. Rev. 1999, 99, 2071. (b) Earle, M. J.; Seddon, K. R. Pure Appl. Chem. 2000, 72, 1391. (c) Hussey, C. L. Adv. Molten Salt Chem. 1983, 5, 185.

(2) (a) Olivier-Bourbigou, H. In Aqueous Phase Organic Metallic Catalysis: Concepts and Applications; Cornils, B., Herrmann, W. A. Eds.; WileyVCH: Weinheim, 1995. (b) Holbrey, J. D.; Seddon, K. R. Clean Prod. Processes 1999, 1, 223. (c) Roney, D. W.; Seddon, K. R. In Handbook of Solvents; Wypych, G., Ed.; ChemTech: Toronto, 2000; Vol. 1, p 1459.

(3) Bonhôte, P.; Dias, A. P.; Papageorgiou, N.; Kalyanasundaram, K., Grätzel, M. Inorg. Chem. 1996, 35, 1168.

(4) (a) Shetty, P. H.; Youngberg, P. J.; Kersten, B. R.; Poole, C. F. J. Chromatogr. 1987, 411, 61. (b) Furton, K. G.; Morales, R. Anal. Chim. Acta 1991, 246, 171 .

374 - Vol. 6, No. 4, 2002 / Organic Process Research \& Development Published on Web 05/25/2002
}

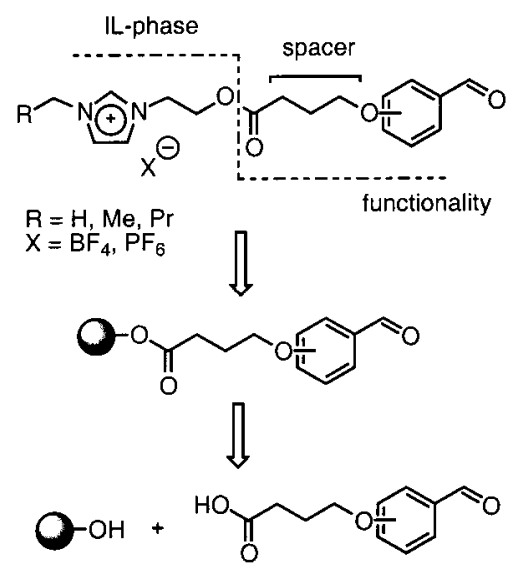

Figure 1. Grafted ionic liquid phases for liquid-phase organic synthesis (LPOS).

high-throughput synthesis and automation technology. ${ }^{8}$ The advantages offered by the use of ionic liquid phases (ILPs) in liquid-phase organic synthesis (LPOS) are the following: (1) ILPs allow standard analytical methods (NMR, TLC) to be used to monitor reaction progress, (2) the routine product isolation is simple because the side product is removed by extraction and washings from the separated IL-phase, (3) it is possible to reuse the IL-phase in another cycle of synthesis, and (4) the IL-phases are easy to prepare and are compatible with a broad spectrum of reactions.

We report in this contribution our results in the preparation of new hydrophilic ionic liquid-phases on which poly-

(5) (a) Olivier-Bourbigou, H.; Magna, L. J. Mol. Catal. A: Chem. 2002, 179 In press. (b) Branco, L. Tetrahedron Lett. 2001, 47, 4405. (c) Ren, R. X.; Ou, W. Tetrahedron Lett. 2001, 42, 8445. (d) Ren, R. X.; Zueva, Ou, W. Tetrahedron Lett. 2001, 42, 8441. (e) Morrison, D. W.; Forbes, D. C., Jr. Davis, J. H. Tetrahedron Lett. 2001, 42, 6053. (f) Fraile, J. M.; Garcia, J. I.; Herrerias, C. I.; Mayoral, J. A.; Carrié, D.; Vaultier, M. Tetrahedron: Asymmetry 2001, 12, 1891.

(6) (a) Wasserscheid, W.; Keim, W. Angew. Chem., Int. Ed. 2000, 39, 3772. (b) Brauer, D. J.; Kottsiepper, K. P.; Liek, C.; Stelzer, O.; Waffenschmidt, H.; Wasserscheid, W. J. Organomet. Chem. 2001, 630, 177. (c) Potdar, M. K.; Mohile, S. S.; Solunkhe, M. M. Tetrahedron Lett. 2001, 42, 9285. (d) Deng, Y.; Peng, J. Tetrahedron Lett. 2001, 42, 5917. (e) Fraga-Dubreuil, J.; Bazureau, J. P. Tetrahedron Lett. 2000, 41, 7351. (f) Fraga-Dubreuil, J.; Bazureau, J. P.; Bourahla, K.; Rhamouni, M.; Hamelin, J. Catal. Commun. 2002, 3. In press. (g) Gordon, C. M. Appl. Catal. 2001, 222, 101. (g) Sheldon, R. J. Chem. Soc., Chem. Commun. 2001, 2399.

(7) (a) Fraga-Dubreuil, J.; Bazureau, J. P. Tetrahedron Lett. 2001, 41, 7351 (b) Presented at the The First International Rhodia Conference: Organic Chemistry, Novel Methods for the Future; Ecole Normale Supérieure de Lyon, 2-5 July 2001, Lyon, France; Poster Abstracts: A-6, p 30.

(8) (a) Stadler, A.; Kappe, C. O. Eur. J. Org. Chem. 2001, 919. (b) Ley, S. V.; Baxendale, J. R.; Bream, R. N.; Jackson, P. S.; Leach, A. G.; Longbottom, D. A.; Nesi, M.; Scott, J. S.; Storer, R. I.; Taylor, S. J. J. Chem. Soc., Perkin Trans. 1 2000, 23, 3815. (c) Lebl, M.; J. Comb. Chem. 1999, 1, 3. 
(ethyleneglycol) units ${ }^{9}$ (PEG) are grafted, using solventless reaction conditions, assisted by focused microwave technology. ${ }^{10}$

\section{Results and Discussion}

Liquid imidazolium salts are generally obtained by anion exchange from imidazolium halide precursors. For the preparation of 1,3-dialkyl imidazolium halides via conventional heating methods in refluxing solvents, the major drawbacks of these common methods are the long reaction time $(12-72 \mathrm{~h})$ to afford reasonable yields and also the use of a large excess of the irritant volatile alkyl halides/organic solvents as reaction medium. In view of our general interest in solventless organic synthesis mediated by microwave $(\mu \omega)$, we decided to explore the preparation of the imidazolium chlorides $\mathbf{3}$ and $\mathbf{6}$ using solvent-free conditions with a focused microwave ${ }^{11}$ reactor (Synthewave 402)..$^{12}$ This reactor operates with an adjustable power range $0-300 \mathrm{~W}$ and may be monitored either in power or in temperature or both.

For this study, the commercial 1-alkyl imidazoles employed were 1-methyl imidazole 1a $(\mathrm{R}=\mathrm{H})$ and 1-butyl imidazole $1 \mathrm{~b}(\mathrm{R}=\mathrm{Pr})$; the chloro alcohols $\mathbf{2}$ and $\mathbf{5}$ used were 2-chloroethanol 2a $(n=1), 2$-(2-chloroethoxy)ethanol 2b $(n=2)$, 2-[2-(2-chloroethoxy)ethoxy]ethanol $\mathbf{2 c}(n=3)$, and 3-chloropropanol 5. We have examined the effect of microwave power on a series of reactions using the chloro alcohols 2(a-c), 5, and 1-alkyl imidazole $\mathbf{1}(\mathbf{a}, \mathbf{b})$ as reactants. Under focused microwave irradiation, the imidazolium salt formed readily, and this increases the polarity of the reaction mixture, thereby increasing the rate of microwave absorption. At elevated power levels, it is possible to observe evaporation of chloro alcohol 2a (or 5) and partial decomposition of the imidazolium salt by microwave absorption, which results in lower yields. To overcome this problem, the reactions were conducted with intermittent microwave heating and continuous mixing at a moderate power level. For example (Table 1), the 1-(2-hydroxy-ethyl)-3-methylimidazolium chloride ([PEG ${ }_{1}$ mim] $\left.[\mathrm{Cl}]\right)$ 3a and the 1-(3-hydroxy-propyl)-3-methylimidazolium chloride ([hypmim][Cl]) 6 were obtained under irradiation after $5 \mathrm{~min}$ at $20 \%$ power level in the first irradiation period (this first period was necessary to reach the plateau value of the bulk-imposed temperature at 180 ${ }^{\circ} \mathrm{C}$ ), and then this microwave heating period was repeated at the same power level.

Results of the synthesis of a series of imidazolium chloride $\mathbf{3}(\mathbf{a}-\mathbf{e})$ and $\mathbf{6}$ using optimized microwave reaction conditions (temperature, reaction time, and power level) are outlined in Table 1.

(9) Sieber, F.; Wentworth, P., Jr.; Janda, K. D. Molecules 2000, 5, 1018

(10) (a) Lidström, P.; Tierney, J.; Wathey, B.; Westman, J. Tetrahedron 2001 57, 9225. (b) Varma, R. S. Green Chem. 1999, 1, 43. (c) Loupy, A.; Petit, A.; Hamelin, J.; Texier-Boullet, F.; Jacquault, P.; Mathé, D. Synthesis 1998, 1213. (d) Caddick, S. Tetrahedron 1995, 51, 10403.

(11) (a) Westmann, J. (Personal Chemistry, Upsala (SE)). WO 00/72956 A1, 2000. (b) Varma, R. S.; Namboodiri, V. J. Chem. Soc., Chem. Commun. 2001, 643 .

(12) (a) Commarmot, R.; Didenot, R.; Gardais, J. F. Fr. Demande, 25560529 1985; Chem. Abstr. 1986, 105, 17442. (b) For descriptions of commercial microwave devices available with adequate mixing and control of reaction parameters, see these Internet sites: http://www.cem.com and http:// www.personalchemistry.com.
Table 1. Optimized reaction conditions for the preparation of (PEG) ${ }_{n}$-imidazolium chlorides $3(\mathrm{a}-\mathrm{e})$ and 6 using a focused microwave reactor (Synthewave 402, Prolabo)

\begin{tabular}{|c|c|c|c|c|}
\hline salt & $\mathrm{R}$ & $n$ & $\begin{array}{l}\text { reaction conditions: } \\
\mathrm{MW} / \text { time/temp/power level }\left(\mathrm{min} /{ }^{\circ} \mathrm{C} / \%\right)\end{array}$ & $\begin{array}{c}\operatorname{yield}^{a} \\
(\%)\end{array}$ \\
\hline $3 \mathbf{a}^{b}$ & $\mathrm{H}$ & 1 & $(5 / 180 / 20)+(5 / 180 / 20)$ & $94^{d}$ \\
\hline $3 \mathbf{b}^{c}$ & $\mathrm{H}$ & 2 & $(2 / 90 / 20)+(4 / 120 / 5)+(24 / 120 / 15)$ & 93 \\
\hline $3 \mathbf{c}^{c}$ & $\mathrm{H}$ & 3 & $(2 / 90 / 20)+(4 / 120 / 5)+(24 / 120 / 15)$ & 95 \\
\hline $\mathbf{3} \mathbf{d}^{c}$ & $\operatorname{Pr}$ & 1 & $(2 / 90 / 20)+(4 / 120 / 5)+(24 / 120 / 15)$ & 74 \\
\hline $3 \mathbf{e}^{c}$ & $\operatorname{Pr}$ & 3 & $(2 / 90 / 20)+(4 / 120 / 5)+(24 / 120 / 15)$ & 73 \\
\hline $\mathbf{6}^{c}$ & $\mathrm{H}$ & - & $(5 / 180 / 20)+(5 / 180 / 20)$ & 94 \\
\hline
\end{tabular}

${ }^{a}$ Isolated yields. ${ }^{b}$ 3a: $\mathrm{mp}=86-88{ }^{\circ} \mathrm{C} .{ }^{c}$ At room temperature, the imidazolium chloride is liquid. ${ }^{d}$ Recrystallization from anhydrous acetonitrile gave 3a in $80 \%$ yield as colourless needles.

It should be noted that the preparation of the imidazolium chlorides $\mathbf{3}(\mathbf{b}-\mathbf{e})$ was optimized using three irradiation heating periods with continuous stirring: 2 min were necessary to reach $90{ }^{\circ} \mathrm{C}$ at $20 \%$ power level, followed by $4 \mathrm{~min}$ at $120{ }^{\circ} \mathrm{C}(P=5 \%)$, and then at the same reaction temperature $\left(120{ }^{\circ} \mathrm{C}\right)$, the reaction mixture was irradiated for $24 \mathrm{~min}$ at $15 \%$ power level.

All the synthesized imidazolium chlorides $\mathbf{3}$ and $\mathbf{6}$ remain liquid for weeks (excepted for $\mathbf{3 a}$ which crystallizes at room temperature at the end of the reaction); they appear to be very hygroscopic and hence were stored in an inert atmosphere at $4{ }^{\circ} \mathrm{C}$ after drying under high vacuum $\left(10^{-2}\right.$ Torr $)$ at $60{ }^{\circ} \mathrm{C}$ for $8 \mathrm{~h}$. Their purity ${ }^{13}$ has been established by acquisition of clean ${ }^{1} \mathrm{H}$ and ${ }^{13} \mathrm{C}$ NMR as well as by FABMS (the purity of the chloride salt can be also controlled by the simple colorimetric Seddon's method ${ }^{14}$ ), and water contents were measured by Karl Fisher titration.

It is probably noteworthly here that the imidazolium salts $\mathbf{3}(\mathbf{a}-\mathbf{e})$ and $\mathbf{6}$ were efficiently synthesized in yields ranging from 73 to $96 \%$ by simple exposure of neat reactants in the reactor to microwaves. This solventless method requires few minutes of reaction time $(10-30 \mathrm{~min})$ in contrast to several hours under classical heating conditions which use an excess of reactants.

In our chemical applications of ionic liquids for liquidphase organic synthesis, the length of the alkyl chain attached to the imidazolium cation influences the physical properties (viscosity, hydrophobicity) of the (PEG) ${ }_{n}$-ionic liquid phases (PEG-ILPs). It appears also that the counteranion has an effect on these physical properties. Driven by the need to find new PEG-ILPs with various viscosity and miscibility ${ }^{15}$ properties, we have prepared a new series of ILPs by anion metathesis exchange of the previous imidazolium chlorides $\mathbf{3}(\mathbf{a}-\mathbf{e})$ and $\mathbf{6}$. For the anion-exchange reactions (Scheme $1)$, the corresponding weakly coordinating anions used were $\mathrm{BF}_{4}{ }^{-}, \mathrm{PF}_{6}{ }^{-}$, and bis((trifluoromethyl)sulfonyl)amide anion ${ }^{16}$ $\left[\mathrm{NTf}_{2}\right]$ from the respective commercially available starting salts $\mathrm{NH}_{4} \mathrm{BF}_{4}, \mathrm{KPF}_{6}$, and $\mathrm{LiN}\left(\mathrm{CF}_{3} \mathrm{SO}_{2}\right)_{2}$ (or $\mathrm{LiNTf}_{2}$ ). All the anion-exchange reactions were carried out in dry acetonitrile

(13) Suarez, P. A. Z.; Einloft, S.; Dullius, J. E. L.; Souz, R. F.; Dupont, J. J. J. Chem. Phys. 1998, 95, 1626.

(14) Holbrey, J. D.; Seddon, K. R.; Warcing, R. Green Chem. 2001, 3, 33.

(15) Gravert, D. J.; Janda, K. D. Chem. Rev. 1997, 97, 489.

(16) (a) Koch, V. R.; Najundiah, C.; Battista-Appetecchi, G.; Scronati, B. J. Electrochem. Soc. 1995, 142, L116. (b) Muldoon, M. J.; Gordon, C. M. Dunkin, I. R. J. Chem. Soc., Perkin Trans. 2 2001, 433. 


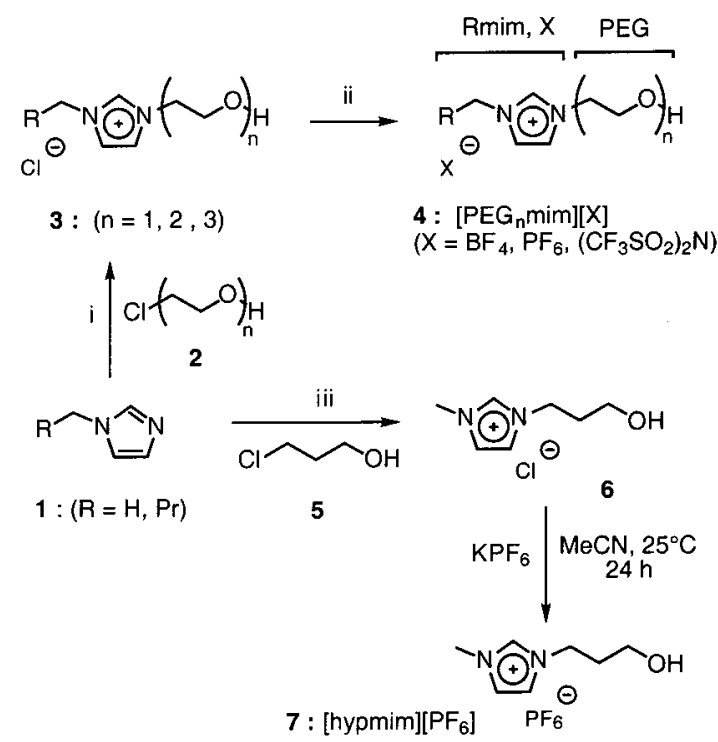

a Reagents and reaction conditions: (i) 31 equiv, $\mu \omega, 120$ or $180^{\circ} \mathrm{C}, 10-30$ min. (ii) $\mathrm{NH}_{4} \mathrm{BF}_{4}$ or $\mathrm{KPF}_{6}$ or $\mathrm{LiN}\left(\mathrm{CF}_{3} \mathrm{SO}_{2}\right)_{2}\left(\mathrm{LiNTf}_{2}\right) 1$ equiv, dry $\mathrm{MeCN}, 25$ ${ }^{\circ} \mathrm{C}, 24$ h. (iii) 51 equiv, $\mu \omega, 10 \mathrm{~min}, 180{ }^{\circ} \mathrm{C}$.

Table 2. Dynamic viscosity at $25{ }^{\circ} \mathrm{C}\left(\mathrm{cP}\left(0.01 \mathrm{~g} \cdot \mathrm{cm}^{-1} \cdot \mathrm{s}^{-1}\right)\right.$ of salts $4(\mathrm{a}-\mathrm{m})$ and 7 which are liquids at $25^{\circ} \mathrm{C}$ after anion metathesis exchange

\begin{tabular}{|c|c|c|c|c|c|c|}
\hline salt & $\mathrm{R}$ & $n$ & $X^{-}$ & $\begin{array}{l}\text { abreviation } \\
\text { of cation }\end{array}$ & $\begin{array}{c}\text { yield }^{a} \\
(\%)\end{array}$ & $\begin{array}{l}\text { viscosity }^{b} \\
\text { (cP) }\end{array}$ \\
\hline $4 a$ & $\mathrm{H}$ & 1 & $\mathrm{BF}_{4}$ & {$\left[\mathrm{PEG}_{1} \operatorname{mim}\right]^{c}$} & 98 & 86 \\
\hline $4 b$ & $\mathrm{H}$ & 1 & $\mathrm{PF}_{6}$ & {$\left[\mathrm{PEG}_{1} \mathrm{mim}^{c}\right]^{c}$} & 98 & 336 \\
\hline $4 c$ & $\mathrm{H}$ & 1 & $\mathrm{NTf}_{2}$ & {$\left[\mathrm{PEG}_{1} \mathrm{mim}\right]^{c}$} & 91 & 541 \\
\hline 4d & $\mathrm{H}$ & 2 & $\mathrm{BF}_{4}$ & {$\left[\mathrm{PEG}_{2} \mathrm{mim}\right]^{d}$} & 98 & 201 \\
\hline $4 e$ & $\mathrm{H}$ & 2 & $\mathrm{PF}_{6}$ & {$\left[\mathrm{PEG}_{2} \mathrm{mim}\right]^{d}$} & 95 & 370 \\
\hline $4 f$ & $\mathrm{H}$ & 2 & $\mathrm{NTf}_{2}$ & {$\left[\mathrm{PEG}_{2} \mathrm{mim}\right]^{d}$} & 92 & 922 \\
\hline $4 \mathrm{~g}$ & $\mathrm{H}$ & 3 & $\mathrm{BF}_{4}$ & {$\left[\mathrm{PEG}_{3} \mathrm{mim}\right]^{e}$} & 92 & 391 \\
\hline $4 \mathrm{~h}$ & $\mathrm{H}$ & 3 & $\mathrm{PF}_{6}$ & {$\left[\mathrm{PEG}_{3} \mathrm{mim}\right]^{e}$} & 95 & 864 \\
\hline $4 \mathbf{i}$ & $\mathrm{H}$ & 3 & $\mathrm{NTf}_{2}$ & {$\left[\mathrm{PEG}_{3} \mathrm{mim}^{e}\right.$} & 83 & 2249 \\
\hline $4 \mathbf{j}$ & Pr & 1 & $\mathrm{BF}_{4}$ & {$\left[\mathrm{PEG}_{1} \mathrm{bim}^{f}\right.$} & 83 & 204 \\
\hline $4 \mathbf{k}$ & $\operatorname{Pr}$ & 1 & $\mathrm{PF}_{6}$ & {$\left[\mathrm{PEG}_{1} \mathrm{bim}^{f}\right.$} & 86 & 542 \\
\hline 41 & $\operatorname{Pr}$ & 1 & $\mathrm{NTf}_{2}$ & {$\left[\mathrm{PEG}_{1} \mathrm{bim}\right]^{f}$} & 99 & $-i$ \\
\hline $4 m$ & $\operatorname{Pr}$ & 3 & $\mathrm{PF}_{6}$ & {$\left[\mathrm{PEG}_{3} \mathrm{bim}^{g}\right.$} & 98 & 923 \\
\hline 7 & $\mathrm{H}$ & - & $\mathrm{PF}_{6}$ & [hypmim] $^{h}$ & 90 & 538 \\
\hline
\end{tabular}

${ }^{a}$ Isolated yield of salt. ${ }^{b}$ Dynamic viscosity $(\mathrm{cP})$ at $25{ }^{\circ} \mathrm{C}$, estimated error $\left.= \pm 5 \% .^{c}{ }^{2} \mathrm{PEG}_{1} \mathrm{mim}\right]:$ 1-(2-hydroxy-ethyl)-3-methylimidazolium. ${ }^{d}$ [PEG $\left.{ }_{2} \mathrm{mim}\right]$ 1-[2-(2-hydroxy-ethoxy)-ethyl]-3-methylimidazolium. ${ }^{e}$ [PEG $\mathrm{PEim}_{3}$ : $1-\{2-[2-$ (2-hydroxy-ethoxy)-ethoxy]-ethyl\}-3-methylimidazolium. ${ }^{f}$ [PEG $\mathrm{PBim}$ ]: 3-butyl1-(2-hydroxy-ethyl)imidazolium. ${ }^{g} \quad\left[\mathrm{PEG}_{3}\right.$ bim]: 3-butyl-1-\{2-[2-(2-hydroxyethoxy)-ethoxy]-ethyl $\}$ imidazolium. ${ }^{h}$ [hypmim]: 1-(3-hydroxy-propyl)-3-methylimidazolium. ${ }^{i} \mathrm{mp} \approx 30^{\circ} \mathrm{C}$.

stirred at room temperature under nitrogen for $24 \mathrm{~h}$ with conventional glassware. After filtration on a pad of Celite to remove $\mathrm{NH}_{4} \mathrm{Cl}$ or $\mathrm{KCl}$ or $\mathrm{LiCl}$ followed by evaporation of the solvent in vacuo, the new PEG-ILPs $\mathbf{4}(\mathbf{a}-\mathbf{n})$ and $\mathbf{7}$ were isolated in good yields (83-98\%) (Table 2) as mobile oils at room temperature (excepted for $\mathbf{4} \mathbf{l}$, but this matrix has a low melting point, $\left.\mathrm{mp} \approx 30^{\circ} \mathrm{C}\right)$. Then, the PEG-ILPs 4 and 7 were dried under high vacuum at $80{ }^{\circ} \mathrm{C}$ for $12 \mathrm{~h}$ without decomposition.

The dynamic viscosities of the (PEG) ${ }_{n}$-ILPs (Table 2) are difficult to correlate with the chemical composition. Usually, the viscosities of the room-temperature ionic liquids ${ }^{17}$ are governed by van der Waals interactions and $\mathrm{H}$-bonding. It appears from the examination of the same imidazolium series that the viscosity depends on the nature of the anions. For example, with the 3-methylimidazolium series $\mathbf{4}(\mathbf{a}-\mathbf{c})(\mathbf{4 a}$ : $\left[\mathrm{PEG}_{1} \mathrm{mim}\right]\left[\mathrm{BF}_{4}\right], \mathbf{4 b}: \quad\left[\mathrm{PEG}_{1} \mathrm{mim}\right]\left[\mathrm{PF}_{6}\right], \mathbf{4 c}:\left[\mathrm{PEG}_{1} \mathrm{mim}\right]-$ $\left[\mathrm{NTf}_{2}\right]$ ), the viscosity increases as follows: $\mathrm{BF}_{4}{ }^{-}<\mathrm{PF}_{6}{ }^{-}<$ $\mathrm{NTf}_{2}{ }^{-}$. Alkyl chain lengthening in the N-3 position of the imidazolium moiety has the same effect $(\mathbf{4}(\mathbf{a}-\mathbf{c})$ and $\mathbf{4}(\mathbf{j}-\mathbf{l})$ series), due to reduced rotation freedom. The high viscosities obtained with the $\mathrm{NTf}_{2}{ }^{-}$salts in each series are probably due to strong H-bonding between the hydroxyl group of the $\mathrm{N}-1$ side chain attached to the imidazolium cation with the $\mathrm{NTf}_{2}{ }^{-}$counteranion which has moderate basicity. The $\mathrm{NTf}_{2}{ }^{-}$ anion ${ }^{18}$ appears more coordinating than the $\mathrm{PF}_{6}{ }^{-}$and $\mathrm{BF}_{4}{ }^{-}$ anions. In the same way, the poly(ethyleneglycol) unit lengthening in $\mathrm{N}-1$ position of the imidazolium cation makes also the ILPs more viscous (from $\mathrm{PEG}_{1}$ mim to $\mathrm{PEG}_{3}$ mim series). The salt $\mathbf{4 a}\left(\left[\mathrm{PEG}_{1} \mathrm{mim}\right]\left[\mathrm{BF}_{4}\right]\right)$ presents the lowest dynamic viscosity as it combines minimal anion weight with weak coordinating properties and the shortest side chain for the cation with moderate cation weight; in this case it seems possible that the van der Waals interactions dominates the H-bonding.

In summary, the poly(ethyleneglycol) ionic liquid-phases (PEG) $)_{n}$-ILPs based on imidazolium cation and three different anions have been studied and prepared in two steps with good yields: the first step involves an efficient solventless quaternization under focused microwave irradiations followed by a facile anion metathesis exchange which produces the expected task-specific ionic liquids. ${ }^{19}$ Future studies are directed to the evaluation and the scope of PEG-ILPs in combinatorial chemistry ${ }^{20}$ mediated by microwave irradiations. $^{21}$

\section{Experimental Section}

General. Melting points were determined on a Kofler melting point apparatus and are uncorrected. ${ }^{1} \mathrm{H}$ NMR spectra were recorded on a Bruker AC $300 \mathrm{P}(300 \mathrm{MHz})$ spectrometer, ${ }^{13} \mathrm{C}$ NMR spectra on a Bruker AC $300 \mathrm{P}(75 \mathrm{MHz})$ spectrometer. Chemical shifts are expressed in parts per million downfield from tetramethylsilane as an internal standard. Unless otherwise stated, $\delta$ values refer to singlet absorptions. Data are given in the following order: $\delta$ value, multiplicity (s, singlet; d, doublet; t, triplet; q, quartet; m, multiplet; br, broad), number of protons, coupling constants $J$ are given in Hertz. The mass spectra (HRMS) were taken on a Varian MAT 311 at a ionizing potential of $70 \mathrm{eV}$ in the Centre Régional de Mesures Physiques de l'Ouest (CRMPO, Rennes). For the dynamic viscosity, the measure-

(17) Bockris, J. O.’M.; Reddy, A. K. N. Modern Electrochemistry; Plenum Press: New York, 1970; Vol. 1, pp 547-543.

(18) (a) McForlane, D. R.; Sun, J.; Golding, J.; Meakin, P.; Forsyth, M.; Electrochim. Acta 2000, 45, 1271. (b) Matsumoto, H.; Kageyama, H.; Miyazaki, Y.; Chem. Lett. 2001, 182.

(19) (a) Bates, E. D.; Mayton, R. D.; Ntai, I.; Davis, J. H., Jr. J. Am. Chem. Soc. 2002, 124, 926. (b) Visser, A. E.; Holbrey, J. D.; Rogers, R. D. J. Chem. Soc., Chem. Commun. 2001, 2484. (c) Visser, A. E.; Swatloski, R. P.; Reichert, W. M.; Sheff, S.; Wierzbicki, A.; Davis, J. H., Jr.; Rogers, R. D. J. Chem. Soc., Chem. Commun. 2001, 135. (d) Merrigan, T. L.; Bates, E. D.; Dorman, S. C.; Davis, J. H., Jr.; J. Chem. Soc., Chem. Commun. 2000, 2051. (e) Forrester, K. J.; Davis J. H., Jr. Tetrahedron Lett. 1999, 40, 1621. (20) Dolle, R. E. J. Comb. Chem. 2001, 3, 477.

(21) Ley, S. V.; Leach, A.; Storer, I. J. Chem. Soc., Perkin Trans. 1 2001, 358. 
ments were carried out at $25^{\circ} \mathrm{C}$ on the AR 1000 microviscosimeter (TA Instruments) with a stainless cone plate geometry (diameter, $40 \mathrm{~mm}$; angle, $1^{\circ} 1^{\prime}$ ). A flow procedure was applied from 0.06 to $200 \mathrm{~s}^{-1}$ in 3 min with 20 points by decade. Water contents were determined by Karl Fischer coulometry using a Metrohm $652 \mathrm{KF}$ coulometer. Solvents were evaporated with a Buchi rotary evaporator. All reagents were purchased from Acros, Aldrich, Avocado, and were used without purification. 1-Methylimidazole 1a and 1-butylimidazole $\mathbf{1 b}$ were distilled from $\mathrm{CaH}_{2}$ prior to use.

Standard Procedure Using a Focused Microwave Oven for (PEG) $)_{n}$-Imidazolium Chlorides 3(a-c) and 6. 1-(2-

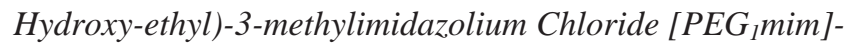
[Cl] (3a). A mixture of freshly distilled 1-methylimidazole 1a (15 g, $182.6 \mathrm{mmol})$ and 2-chloroethanol 2a (14.70 g, $182.6 \mathrm{mmol})$ was placed in a cylindrical quartz reactor $(\varnothing$ $=4 \mathrm{~cm}$ ). The reactor was then introduced into a Synthewave 402 Prolabo microwave reactor [2.45 GHz, adjusted power within the range $0-300 \mathrm{~W}$ and a waveguide (single mode $T_{01}$ ) fitted with a stirring device and an IR temperature detector]. The stirred liquid mixture was irradiated twice at $20 \%$ power level for $5 \mathrm{~min}$ at $180{ }^{\circ} \mathrm{C}$. Then the mixture was allowed to cool, and a white solid formed rapidly ( $\sim 5 \mathrm{~min}$.) at $25{ }^{\circ} \mathrm{C}$. The crude solid formed was filtered off (under nitrogen), washed successively with anhydrous ether $(3 \times$ $30 \mathrm{~mL})$ and dry acetonitrile $(2 \times 20 \mathrm{~mL})$ and vacuum-dried in a desiccator over $\mathrm{CaCl}_{2}$ for $1 \mathrm{~h}$. The solid salt $\left[\mathrm{PEG}_{1}\right.$ $\operatorname{mim}][\mathrm{Cl}]$ 3a was further dried under high vacuum $\left(10^{-2}\right.$ Torr) at $60{ }^{\circ} \mathrm{C}$ for $8 \mathrm{~h}$ and was stored (23.44 g, 94\% yield) in the dark at $4{ }^{\circ} \mathrm{C}$ under nitrogen. Recrystallization from dry $\mathrm{MeCN}$ gave $\mathbf{3 a}$ in $80 \%$ yield as colourless needles (mp $=86-88^{\circ} \mathrm{C}$ ).

Standard Experimental Procedure for the Preparation of Liquid (PEG) -Imidazolium Matrix 4 and 7 by Anion Exchange. (a) From $\mathrm{NH}_{4} \mathrm{BF}_{4}$ and $\mathrm{KPF}_{6}$. A mixture of $(\mathrm{PEG})_{n}$-imidazolium chloride 3 or $\mathbf{6}$ (1 equiv) and $\mathrm{NH}_{4} \mathrm{BF}_{4}$ or $\mathrm{KPF}_{6}(1$ equiv) in dry acetonitrile $(1: 10 \mathrm{w} / \mathrm{v})$ was stirred vigorously at $25^{\circ} \mathrm{C}$ under nitrogen for $24 \mathrm{~h}$. After elimination of the precipitated salt $\left(\mathrm{NH}_{4} \mathrm{Cl}\right.$ or $\left.\mathrm{KCl}\right)$ on a filter paper, the resulting filtrate was quickly refiltered through a short column of Celite to remove some residual salt and finally concentrated by rotary evaporation that gave a mobile liquid. The ionic liquid phase 3 or 7 with $\mathrm{BF}_{4}^{-}$or $\mathrm{PF}_{6}^{-}$as counteranion were further dried under high vacuum $\left(10^{-2}\right.$ Torr) at $60{ }^{\circ} \mathrm{C}$ for $6 \mathrm{~h}$. It is recommended to handle the $(\mathrm{PEG})_{n}$-ionic liquid phase $\mathbf{3}$ or $\mathbf{7}$ in the dark under an inert atmosphere at $4{ }^{\circ} \mathrm{C}$.

(b) From Lithium Bis((trifluoromethyl)sulfonyl)amide LiNTf $_{2}$. The (PEG) $)_{n}$-ionic liquid phases $\mathbf{4 c}, \mathbf{4 f}, \mathbf{4 i}$, and $\mathbf{4 1}$ were prepared from a solution of (PEG) $)_{n}$-imidazolium chloride 3 (1 equiv) and lithium bis((trifluoromethyl)sulfonyl)amidure (1 equiv) in anhydrous acetonitrile $(1: 10 \mathrm{w} / \mathrm{v})$. The solution was magnetically stirred at $25^{\circ} \mathrm{C}$ under nitrogen for $24 \mathrm{~h}$. After removal of solvent under reduced pressure, dry acetone was added to the crude reaction mixture for compounds $\mathbf{4 c}$, 4f, and 4i (or dry methylene chloride for $\mathbf{4 1}$ ). The resulting solution was rapidly filtered through a short column of Celite to remove the precipitated $\mathrm{LiCl}$, then the filtrate was refiltered to ensure the complete elimination of $\mathrm{LiCl}$, and the solvent was removed on a Rotavapor. For drying, the same procedure was used as for the $(\mathrm{PEG})_{n}$-ionic liquid phases obtained from $\mathrm{NH}_{4} \mathrm{BF}_{4}$ or $\mathrm{KPF}_{6}$.

Selected spectral data of 1-(2-hydroxy-ethyl)-3-methylimidazolium tetrafluoroborate $\left[\mathrm{PEG}_{1} \mathrm{mim}_{[}\left[\mathrm{BF}_{4}\right](\mathbf{4 a}):{ }^{1} \mathrm{H} \mathrm{NMR}\right.$ (300 MHz, $\left.\left(\mathrm{CD}_{3}\right)_{2} \mathrm{CO}, \mathrm{TMS}\right) \delta 3.92(\mathrm{t}, 3 \mathrm{H}, J=4.8 \mathrm{~Hz})$; $4.01(\mathrm{~s}, 3 \mathrm{H}) ; 4.22(\mathrm{br} \mathrm{s}, 1 \mathrm{H}, \mathrm{OH}) ; 4.38(\mathrm{t}, 3 \mathrm{H}, J=5.1 \mathrm{~Hz})$; $7.63(\mathrm{t}, 1 \mathrm{H}, J=1.55 \mathrm{~Hz}, \mathrm{H}-5) .7 .68(\mathrm{t}, 1 \mathrm{H}, J=1.58 \mathrm{~Hz}$, $\mathrm{H}-4) ; 8.85$ (broad s, $1 \mathrm{H}, \mathrm{H}-2) .{ }^{13} \mathrm{C} \mathrm{NMR}\left(75 \mathrm{MHz},\left(\mathrm{CD}_{3}\right)_{2^{-}}\right.$ CO, TMS) $\delta 36.40(\mathrm{q}, J=144 \mathrm{~Hz}) ; 52.82(\mathrm{t}, J=144 \mathrm{~Hz})$; 60.95 (t, $J=143 \mathrm{~Hz}) ; 123.71(\mathrm{dm}, J=203 \mathrm{~Hz}, \mathrm{C}-5) ; 124.34$ $(\mathrm{dm}, J=203 \mathrm{~Hz}, \mathrm{C}-4) ; 137.71$ (dd, $J=222 \mathrm{~Hz}, \mathrm{C}-2)$. HRMS $m / z$ : 127.0871 found (calcd for $\mathrm{C}_{6} \mathrm{H}_{11} \mathrm{~N}_{2} \mathrm{O}, \mathrm{M}^{+}$ requires: 127.0871$)$.

1-(2-Hydroxy-ethyl)-3-methylimidazolium hexafluorophosphate $\left[P E G_{1}\right.$ mim $]\left[\mathrm{PF}_{6}\right](\mathbf{4 b}) .{ }^{1} \mathrm{H} \mathrm{NMR}\left(300 \mathrm{MHz},\left(\mathrm{CD}_{3}\right)_{2}-\right.$ CO, TMS) $\delta 3.92(\mathrm{t}, 3 \mathrm{H}, J=4.8 \mathrm{~Hz}) ; 4.01(\mathrm{~s}, 3 \mathrm{H}) ; 4.22(\mathrm{br}$ $\mathrm{s}, 1 \mathrm{H}, \mathrm{OH}) ; 4.38(\mathrm{t}, 3 \mathrm{H}, J=5.1 \mathrm{~Hz}) ; 7.63(\mathrm{t}, 1 \mathrm{H}, J=1.55$ Hz, H-5). 7.68 (t, 1H, $J=1.58 \mathrm{~Hz}, \mathrm{H}-4) ; 8.85($ broad s, $1 \mathrm{H}$, $\mathrm{H}-2) .{ }^{13} \mathrm{C} \mathrm{NMR}\left(75 \mathrm{MHz},\left(\mathrm{CD}_{3}\right)_{2} \mathrm{CO}, \mathrm{TMS}\right) \delta 36.40$ (q, $J=$ $144 \mathrm{~Hz}) ; 52.82(\mathrm{t}, J=144 \mathrm{~Hz}) ; 60.95(\mathrm{t}, J=143 \mathrm{~Hz}) ; 123.71$ $(\mathrm{dm}, J=203 \mathrm{~Hz}, \mathrm{C}-5) ; 124.34$ (dm, $J=203 \mathrm{~Hz}, \mathrm{C}-4)$; 137.71 (dd, $J=222 \mathrm{~Hz}, \mathrm{C}-2)$. HRMS $m / z: 399.1384$ found (calcd for $\mathrm{C}_{12} \mathrm{H}_{22} \mathrm{~N}_{4} \mathrm{O}_{2} \mathrm{~F}_{6} \mathrm{P},\left[2 \mathrm{C}^{+}, \mathrm{PF}_{6}{ }^{-}\right]^{+}$requires: 399.1385).

1-[2-(2-Hydroxy-ethoxy)-ethyl]-3-methylimidazolium hexafluorophosphate [PEG ${ }_{2} \mathrm{mim}_{[}\left[\mathrm{PF}_{6}\right](\mathbf{4 e}) .{ }^{1} \mathrm{H} \mathrm{NMR}(300 \mathrm{MHz}$, $\left.\left(\mathrm{CD}_{3}\right)_{2} \mathrm{CO} \mathrm{TMS}\right) \delta 3.63(\mathrm{dtd}, 4 \mathrm{H}, J=24.3,5.8,0.86 \mathrm{~Hz})$; 3.81 (br s, $1 \mathrm{H}, \mathrm{OH}) ; 3.90$ (t, $2 \mathrm{H}, J=6 \mathrm{hz}) ; 4.00$ (s, 3H); $4.48(\mathrm{t}, 2 \mathrm{H}, J=5.7 \mathrm{~Hz}) ; 7.60(\mathrm{t}, 1 \mathrm{H}, J=1.7 \mathrm{~Hz}, \mathrm{H}-4) ; 7.70$ $(\mathrm{t}, 1 \mathrm{H}, J=1.7 \mathrm{~Hz}, \mathrm{H}-5) ; 8.90(\mathrm{~s}, 1 \mathrm{H}, \mathrm{H}-2) .{ }^{13} \mathrm{C} \mathrm{NMR}(75$ $\left.\mathrm{MHz},\left(\mathrm{CD}_{3}\right)_{2} \mathrm{CO}, \mathrm{TMS}\right) \delta 36.55(\mathrm{q}, J=144 \mathrm{~Hz}) ; 50.43(\mathrm{t}$, $J=144 \mathrm{~Hz}) ; 61.78$ (tt, $J=142,2.6 \mathrm{~Hz}) ; 69.30$ (tqt, $J=$ $144,3.1 \mathrm{~Hz}$ ); 73.33 (tqt, $J=141,2.2 \mathrm{~Hz}) ; 123.93 ; 124.28$ $(\mathrm{dm}, J=204 \mathrm{~Hz}, \mathrm{C}-4, \mathrm{C}-5) ; 137.89$ (dm, $J=122 \mathrm{~Hz}, \mathrm{C}-2)$. HRMS $m / z$ : 487.1899 found (calcd for $\mathrm{C}_{16} \mathrm{H}_{30} \mathrm{~N}_{4} \mathrm{O}_{4} \mathrm{~F}_{6} \mathrm{P},\left[2 \mathrm{C}^{+}\right.$, $\left.\mathrm{PF}_{6}{ }^{-}\right]^{+}$requires: 487.1909).

1-\{2-[2-(2-Hydroxy-ethoxy)-ethoxy]-ethyl\}-3-methyl imidazolium bis((trifluoromethyl)sulfonyl)amide [PEG 3 mim][NTf $f_{2}$ (4i). ${ }^{1} \mathrm{H}$ NMR $\left(300 \mathrm{MHz},\left(\mathrm{CD}_{3}\right)_{2} \mathrm{CO}, \mathrm{TMS}\right) \delta 3.55-$ $3.73(\mathrm{~m}, 8 \mathrm{H}) ; 3.94(\mathrm{t}, 2 \mathrm{H}, J=4.9 \mathrm{~Hz}) ; 4.06(\mathrm{~s}, 3 \mathrm{H}) ; 4.18$ (br s, 1H, OH); $4.53(\mathrm{t}, 2 \mathrm{H}, J=4.9 \mathrm{~Hz}) ; 7.67(\mathrm{t}, 1 \mathrm{H}, J=$ $1.7 \mathrm{~Hz}, \mathrm{H}-4) ; 7.77$ (t, $1 \mathrm{H}, J=1.7 \mathrm{~Hz}, \mathrm{H}-5) ; 9.13(\mathrm{~s}, 1 \mathrm{H}$, $\mathrm{H}-2) .{ }^{13} \mathrm{C}$ NMR $\left(75 \mathrm{MHz},\left(\mathrm{CD}_{3}\right)_{2} \mathrm{CO}, \mathrm{TMS}\right) \delta 36.62$ (q, $J=$ $143 \mathrm{~Hz}) ; 50.34$ (t, $J=144 \mathrm{~Hz}) ; 61.73$ (tt, $J=141,2.6 \mathrm{~Hz})$; $69.31(\mathrm{tt}, J=145,3.1 \mathrm{~Hz}) ; 70.73(\mathrm{tt}, J=141,2.9 \mathrm{~Hz})$; 70.81 (tt, $J=142,3.5 \mathrm{~Hz}) ; 73.16(\mathrm{tt}, J=143,2.6 \mathrm{~Hz})$; 120.93 (q, $\left.J=321 \mathrm{~Hz}, \mathrm{CF}_{3}\right) ; 123.97$ (dm, $\left.J=202 \mathrm{~Hz}, \mathrm{C}-4\right)$; 124.30 (dm, $J=202 \mathrm{~Hz}, \mathrm{C}-5)$; $138.05(\mathrm{dm}, J=225 \mathrm{~Hz}$, C-2). HRMS $m / z$ : 215.1396 found (calcd for $\mathrm{C}_{10} \mathrm{H}_{19} \mathrm{~N}_{2} \mathrm{O}_{3}$, $\mathrm{M}^{+}$requires: 215.1396$)$.

3-butyl-1-(2-hydroxy-ethyl)imidazolium hexafluorophosphate $\left[P E G_{1}\right.$ bim $]\left[\mathrm{PF}_{6}\right](\mathbf{4 k}) .{ }^{1} \mathrm{H} \mathrm{NMR}\left(300 \mathrm{MHz},\left(\mathrm{CD}_{3}\right)_{2}-\right.$ CO, TMS) $\delta 0.95(\mathrm{t}, 3 \mathrm{H}, J=7.4 \mathrm{~Hz}) ; 1.39$ (sext, $2 \mathrm{H}, J=$ $7.3 \mathrm{~Hz}$ ); 1.93 (quint, $2 \mathrm{H}, J=7.6 \mathrm{~Hz}$ ); 3.97 (t, 2H, $J=4.9$ $\mathrm{Hz}) ; 4.16$ (br s, 1H, OH); 4.35 (t, 2H, $J=7.3 \mathrm{~Hz}) ; 4.42(\mathrm{t}$, $2 \mathrm{H}, J=5.1 \mathrm{~Hz}) ; 7.72$ (s, 1H, H-4); 7.73 (s, 1H, H-5); 8.95 (s, 1H, H-2). ${ }^{13} \mathrm{C}$ NMR (75 MHz, $\left(\mathrm{CD}_{3}\right)_{2} \mathrm{CO}$, TMS) $\delta 13.70$ 
(qt, $J=125 \mathrm{~Hz}) ; 19.97$ (tsext, $J=125,4.1 \mathrm{~Hz}) ; 32.74(\mathrm{tm}$, $J=125 \mathrm{~Hz}) ; 50.24(\mathrm{tm}, J=145 \mathrm{~Hz}) ; 53.08(\mathrm{t}, J=143$ $\mathrm{Hz}) ; 60.94(\mathrm{tt}, J=144,2.9 \mathrm{~Hz}) ; 123.24(\mathrm{dm}, J=202 \mathrm{~Hz}$, C-4); 124.00 (dm, $J=202 \mathrm{~Hz}, \mathrm{C}-5) ; 137.07$ (dm, $J=222$ $\mathrm{Hz}, \mathrm{C}-2$ ). HRMS $m / z$ : 483.2328 found (calcd for $\mathrm{C}_{18} \mathrm{H}_{34} \mathrm{~N}_{4}$ $\mathrm{O}_{2} \mathrm{~F}_{6} \mathrm{P},\left[2 \mathrm{C}^{+}, \mathrm{PF}_{6}^{-}\right]^{+}$requires: 483.2324).

3-Butyl-1-\{2-[2-(2-hydroxy-ethoxy)-ethoxy]-ethyl $\}$ imidazolium hexafluorophosphate $\left[P E G_{3}\right.$ bim $]\left[P F_{6}\right](\mathbf{4 m}) .{ }^{1} \mathrm{H}$ NMR $\left(300 \mathrm{MHz},\left(\mathrm{CD}_{3}\right)_{2} \mathrm{CO}\right.$, TMS) $\delta 0.95(\mathrm{t}, 3 \mathrm{H}, J=7.4$ $\mathrm{Hz}$ ); 1.38 (sext, $2 \mathrm{H}, J=7.5 \mathrm{~Hz}$ ); 1.92 (quint, $2 \mathrm{H}, J=7.6$ $\mathrm{Hz}) ; 3.52-3.70(\mathrm{~m}, 8 \mathrm{H}) ; 3.92(\mathrm{t}, 2 \mathrm{H}, J=4.7 \mathrm{~Hz}) ; 3.98(\mathrm{br}$ $\mathrm{s}, 1 \mathrm{H}, \mathrm{OH}) ; 4.36(\mathrm{t}, 2 \mathrm{H}, J=7.3 \mathrm{~Hz}) ; 4.49(\mathrm{t}, 2 \mathrm{H}, \mathrm{J} 4.9 \mathrm{~Hz})$; $7.71(\mathrm{t}, J=1.8 \mathrm{~Hz}, \mathrm{H}-4) ; 7.75$ (t, $1 \mathrm{H}, J=1.8 \mathrm{~Hz}, \mathrm{H}-5)$; $9.02(\mathrm{~s}, 1 \mathrm{H}, \mathrm{H}-2) .{ }^{13} \mathrm{C} \mathrm{NMR}\left(75 \mathrm{MHz},\left(\mathrm{CD}_{3}\right)_{2} \mathrm{CO}, \mathrm{TMS}\right) \delta$ 13.65 (qt, $J=125,3.9 \mathrm{~Hz}) ; 19.91$ (tsext; $J=125,4.1 \mathrm{~Hz}$ ); $32.70(\mathrm{tm}, J=129 \mathrm{~Hz}) ; 50.16(\mathrm{tm}, J=145 \mathrm{~Hz}) ; 50.37(\mathrm{t}$, $J=145 \mathrm{~Hz}) ; 61.89$ (tt, $J=140,2.6 \mathrm{~Hz}) ; 69.19(\mathrm{tt}, J=145$, $3.2 \mathrm{~Hz}) ; 70.80(\mathrm{tm}, J=140 \mathrm{~Hz}) ; 70.83(\mathrm{tm} ; J=140 \mathrm{~Hz})$; 73.37 (tt, $J=140,2.8 \mathrm{~Hz}) ; 123.01$ (dm, $J=202 \mathrm{~Hz}, \mathrm{C}-4)$; 124.07 (dm, $J=202 \mathrm{~Hz}, \mathrm{C}-5)$; $137.25(\mathrm{dm}, J=225 \mathrm{~Hz}$, C-2). HRMS m/z: 659.3369 found (calcd for $\mathrm{C}_{26} \mathrm{H}_{50} \mathrm{~N}_{4} \mathrm{O}_{6} \mathrm{~F}_{6} \mathrm{P}$, $\left[2 \mathrm{C}^{+}, \mathrm{PF}_{6^{-}}\right]^{+}$requires: 659.3372).
1-(3-Hydroxy-propyl)-3-methylimidazolium hexafluorophosphate [hypmim][PF 6 (7). ${ }^{1} \mathrm{H} \mathrm{NMR}\left(300 \mathrm{MHz},\left(\mathrm{CD}_{3}\right)_{2}\right.$ $\mathrm{CO}, \mathrm{TMS}$ ) $\delta 2.12$ (quint, $2 \mathrm{H}, J=6.9 \mathrm{~Hz}$ ); $3.63(\mathrm{t}, 2 \mathrm{H}, J=$ $5.9 \mathrm{~Hz}) ; 3.78$ (br s, 1H, OH); $4.01(\mathrm{~s}, 3 \mathrm{H}) ; 4.43(\mathrm{t}, 2 \mathrm{H}, J=$ $7.1 \mathrm{~Hz}) ; 7.64(\mathrm{t}, 1 \mathrm{H}, J=1.6 \mathrm{~Hz}, \mathrm{H}-4) ; 7.70(\mathrm{t}, 1 \mathrm{H}, J=1.6$ $\mathrm{Hz}, \mathrm{H}-5) ; 8.88$ (s, $1 \mathrm{H}) .{ }^{13} \mathrm{C} \mathrm{NMR}\left(75 \mathrm{MHz},\left(\mathrm{CD}_{3}\right)_{2} \mathrm{CO}, \mathrm{TMS}\right)$ $\delta 33.21(\mathrm{tm}, J=128 \mathrm{~Hz}) ; 36.49(\mathrm{q}, J=144 \mathrm{~Hz}) ; 47.62$ (tm, $J=142 \mathrm{~Hz}$ ); 58.83 (tquint, $J=142,3.9 \mathrm{~Hz}$ ); 123.46 $(\mathrm{dm}, J=202 \mathrm{~Hz}, \mathrm{C}-4) ; 124.60$ (dm, $J=202 \mathrm{~Hz}, \mathrm{C}-5)$; 137.50 (dm, $J=222 \mathrm{~Hz}, \mathrm{C}-2)$. HRMS $m / z$ : 427.1694 found (calcd for $\mathrm{C}_{14} \mathrm{H}_{26} \mathrm{~N}_{4} \mathrm{O}_{2} \mathrm{~F}_{6} \mathrm{P},\left[2 \mathrm{C}^{+}, \mathrm{PF}_{6}{ }^{-}\right]^{+}$requires: 427.1698).

\section{Acknowledgment}

J.F.-D. thanks the "Ministère de la Recherche et de l'Enseignement Supérieur" for a research fellowship. We also thank Professor Jack Hamelin for fruitful discussions and Dr Pierre Guénot (CRMPO) for the mass spectrometry measurements.

Received for review February 13, 2002.

OP020027Y 